\title{
PENGARUH KONSEP DIRI, TEMAN SEBAYA DAN BUDAYA KONTEMPORER TERHADAP PERILAKU KONSUMTIF SISWA SMP NEGERI 41 SURABAYA
}

\author{
Dwi Murwanti, SMP Negeri 41 Surabaya \\ dwimurwantismp41@gmail.com
}

\begin{abstract}
ABSTRAK
Tujuan dari penelitian ini adalah untuk mengetahui pengaruh konsep diri, teman sebaya dan budaya kontemporer secara parsial terhadap perilaku konsumtif siswa kelas VII, VIII dan IX di SMP Negeri 41 Surabaya, dan pengaruh konsep diri, teman sebaya dan budaya kontemporer secara bersama-sama terhadap perilaku konsumtif siswa kelas VII, VIII dan IX di SMP Negeri 41 Surabaya Tahun Pembelajaran 2014/2015. Penelitian ini adalah penelitian korelasional dan menggunakan pendekatan kuantitatif. Teknik angket digunakan untuk mengumpulkan data dengan obyek penelitian di SMP Negeri 41 Surabaya. Penentuan sample penelitian menggunakan teknik simple random sampling sebanyak 291 siswa kelas VII, VIII dan IX dari total populasi sebanyak 1070 siswa. Teknik menganalisa data menggunakan analisis regresi linier berganda. Berdasarkan analisis data dapat disimpulkan bahwa: Konsep diri berpengaruh signifikan terhadap perilaku konsumen, mengisyaratkan bahwa konsep diri yang kuat ada kecenderungan perilaku konsumtifnya juga meningkat apabila ada konflik. Teman sebaya berpengaruh signifikan terhadap perilaku konsumtif, disebabkan persahabatan. Budaya kontemporer secara bersama-sama berpengaruh signifikan terhadap perilaku konsumtif. Konsep diri, teman sebaya dan budaya kontemporer secara bersama-sama berpengaruh signifikan terhadap perilaku konsumtif hal ini karena adanya konflik sehingga konsep diri yang kuat bisa terpengaruh terhadap perilaku konsumtif, begitu juga dengan teman sebaya dan budaya kontemporer.
\end{abstract}

Kata Kunci: konsep diri, teman sebaya, budaya kontemporer dan perilaku konsumtif.

\begin{abstract}
The purpose of this study was to determine influence of self concept, peer group and contemporary culture by partial to consumptive behavior On the students of Junior High Schools 41 Surabaya, and The influence of self concept, peer group and contemporary culture jointly to consumptive behavior of students at Junior High Schools 41 in Surabaya. This study was a correlational research and using quantitative approach. Questionnaire technique used to collect data with research object in SMP Negeri 41 Surabaya. Sample determination research use simple random sampling technique as much as 291 students of VII, VIII and IX class from total population of 1070 students. Technique analyze data is using multiple
\end{abstract}


regression analysis. Based on data analysis can be concluded that: The self concept itself have a significant effect on consumptive behavior, indicated that the stroneg self concept tendency consumptive behavior also increase if there is a conflict. Peers also has a significant effect on consumptive behavior, due to the friendship. Contemporary culture also has a significant effect on consumptive behavior it is because of a conflict so that the concept of a strong self could be affected on consumptive behavior, as well as peer and contemporary. The concept of self, peer and contemporary culture jointly give a significant effect on consumptive behavior, it is because of a conflict so that the strong self concept could be affected on consumptive behavior, as well as peer and contemporary culture.

Keywords: self concept, peer group, contemporary culture and consumptive behavior.

\section{PENDAHULUAN}

Perilaku konsumtif dapat diartikan sebagai suatu tindakan menggunakan suatu produk secara tidak tuntas (Sumartono, 2002). Artinya belum habis suatu produk dipakai, seseorang telah menggunakan produk jenis yang sama dari merek lain atau membeli barang karena adanya hadiah yang ditawarkan atau membeli suatu produk karena banyak orang yang menggunakan produk tersebut. Salah satu faktor perilaku konsumtif dipengaruhi oleh tidak adanya konsep diri. Gumulya dan Widiastuti (2013) menyatakan bahwa mahasiswa yang berperilaku konsumtif karena ingin mempercantik dirinya, atau ingin membuat dirinya terlihat lebih baik dipandangan orang lain diduga adalah mahasiswa yang memiliki konsep diri negatif, karena mereka berusaha untuk membuat dirinya tampak ideal di lingkungannya.

Perilaku konsumtif dipengaruhi oleh teman sebaya. Santrock (2007) mengatakan bahwa kawan-kawan sebaya adalah anak-anak atau remaja yang memiliki usia atau tingkat kematangan yang kurang lebih sama. Kelompok teman sebaya merupakan hubungan persahabatan pada anak sekolah pada umumnya terjadi atas dasar ketertarikan dan aktivitas bersama yang bersifat timbal balik dan memiliki sifat-sifat antara lain adanya saling pengertian, saling membantu, saling percaya, saling menghargai dan menerima.

Selain itu perilaku konsumtif dari siswa juga tergantung seberapa besar pengaruh budaya yang ada di lingkungan sekitarnya dan kelas sosial yang dimiliki tiap individu. Keadaan ekonomi tiap individu yang berbeda dapat mempengaruhi diri mereka untuk mengkonsumsi barang yang berlebihan sebagai bentuk bahwa remaja dapat mengikuti perkembangan yang terjadi saat ini (Primadini dan Budiani, 2014). Dari proses inilah kenudian timbul adanya dimensi gaya hidup yang berhubungan dengan aktivitas (bagaimana seseorang dapat melakukan aktivitas dalam menghabiskan waktu luangnya), minat (apa yang menarik atau yang paling penting dari diri seseorang), dan opini (pendapat dan pandangan mereka terhadap dunia mereka dan dunia sekitarnya) (Sumarwan, 2011).

Konsep diri adalah kumpulan keyakinan dan persepsi diri mengenai diri sendiri yang terorganisasi dengan kata lain, Konsep diri tersebut bekerja 
sebagai skema dasar. Diri memberikan sebuah kerangka berpikir yang menentukan bagaimana mengolah informasi tentang diri sendiri, termasuk motivasi, keadaan emosional, evaluasi diri, Kemampuan, dan banyak hal lainnya (Baron, 2003). Dariyo (2007) konsep diri (self-concept) ialah gambaran diri sendiri yang bersifat menyeluruh terhadap keberadaan diri seseorang. Konsep diri ini bersifat multi-aspek yaitu meliputi 4 (empat) aspek seperti (1) aspek fisiologis, (2) psikologis, (3) psikososiologis, (4) psiko-etika dan moral. Gambaran konsep diri berasal dari interaksi antara diri sendiri maupun antara diri dengan orang lain (lingkungan sosialnya).

Menurut Tirtarahardja (2005) lingkungan pendidikan pertama dan utama adalah keluarga. Makin bertambah usia seseorang peranan lingkungan pendidikan lainnya (yakni sekolah dan masyarakat) semakin penting meskipun pengaruh lingkungan keluarga masih tetap berlanjut. Teman sebaya adalah sebagai dua atau lebih banyak orang yang berinteraksi untuk mencapai baik tujuan-tujuan individual atau timbal balik. (Kiriinya, dkk 2014). Dalam kelompok sebaya itu anak belajar memberi dan menerima dalam pergaulannya dengan sesama temannya. Partisipasi di dalam kelompok sebayanya memberikan kesempatan yang besar bagi anak mengalami proses belajar sosial (social learning). Bergaul dengan teman sebaya merupakan persiapan penting dalam kehidupan seseorang setelah dewasa. Kelompok sebaya anak mempelajari kebudayaan masyarakat. Bahwa melalui kelompok sebaya itu anak belajar bagaimana menjadi manusia yang baik sesuai dengan gambaran dan cita-cita masyarakatnya, tentang kejujuran, keadilan, kerja sama, dan tanggung jawab..

Herskovits dan Malinowski (2004) dalam Soekamto (2007) mengemukakan bahwa segala sesuatu yang terdapat dalam masyarakat ditentukan oleh kebudayaan yang dimiliki oleh masyarakat itu sendiri. Budaya adalah suatu cara hidup yang berkembang dan dimiliki bersama oleh sebuah kelompok orang dan diwariskan dari generasi ke generasi. Budaya terbentuk dari banyak unsur yang rumit, termasuk sistem agama dan politik, adat istiadat, bahasa, perkakas, pakaian, bangunan, dan karya seni. Bahasa, sebagaimana juga budaya, merupakan bagian tak terpisahkan dari diri manusia sehingga banyak orang cenderung menganggapnya diwariskan secara genetis. Budaya yang dipengaruhi oleh era globalisasi akan berubah menjadi budaya kontemporer yaitu budaya yang terbentuk adanya gaya hidup yang dipengaruhi oleh era globalisasi (Wang dan Xu, 2009). Seperti yang terjadi pada mahasiswa yang ada di Cina dimana budayanya menjadi berubah yaitu budaya kontemporer yaitu suatu budaya yang terlibat atau menjadi bagian dari kelompok dimana kuliah di universitas.

Perilaku konsumtif adalah pembelian yang terjadi ketika konsumen tibatiba mengalami keinginan yang kuat dan kokoh untuk membeli sesuatu secepatnya atau kecenderungan pembelanja belanja disekitar, secara spontan (Saad dan Metawie, 2015). Mangkunegara (2002) perilaku konsumtif sebagai tindakan-tindakan individu yang secara langsung terlibat dalam usaha memperoleh dan menggunakan barang-barang jasa ekonomis termasuk proses pengambilan keputusan yang mendahului dan menentukan tindakan-tindakan tersebut. Perilaku konsumtif adalah keinginan untuk mengkonsumsi barangbarang yang sebenarnya kurang diperlukan secara berlebihan untuk mencapai 
kepuasan yang maksimal. Konsumen memanfaatkan nilai uang lebih besar dari nilai produksinya untuk barang dan jasa yang bukan menjadi kebutuhan pokok. Budaya konsumtif menimbulkan kecanduan dalam belanja. Biasanya orangorang tidak menyadari dirinya terjebak diantara keinginan dan kebutuhan. Ini bisa menyerang siapa saja, baik perempuan maupun laki-laki.

Menurut Pimthong (2015) menyimpulkan bahwa 1) Perilaku konsumsi cukup berpengaruh langsung oleh materialisme, sikap terhadap perilaku konsumsi siswa. 2) Ada satu perbedaan dalam model struktur faktor penyebab antara siswa-siswa di Thailand dan Malaysia. Efek langsung masa depan orientasi \& pengendalian diri di sikap mereka terhadap perilaku konsumsi cukup berbeda, 3) Laten berarti dari perilaku konsumsi cukup, sikap berpengaruh terhadap perilaku konsumsi. Nayeem (2012) menyimpulkan bahwa Pelanggan-pelanggan kelahiran Asia adalah lebih banyak dan melibatkan sejumlah keluarga / teman dalam pengambilan keputusan dan pelanggan-pelanggan kelahiran orang Australia tidak percaya akan keputusan kelompok. Menurut Makgosa and Mohube (2007) menyimpulkan bahwa ada pengaruh yang lebih normatif untuk satu kemewahan (kacamata hitam) daripada untuk satu kemewahan (telepon seluler) dan kebutuhan (odol). Menurut Kiriinya, Bwisa, dan Orwa (2014) menyimpulkan bahwa anak secara signifikan mempengaruhi keputusan pembelian keluarga di Kenya, disebabkan adanya tekanan teman sebaya.

Dengan demikian, tujuan penelitian ini diantaranya: (1) Menganalisis pengaruh konsep diri terhadap perilaku konsumtif siswa kelas VII, VIII dan IX di SMP Negeri 41 Surabaya Tahun Pembelajaran 2014/2015. (2) Menganalisis pengaruh teman sebaya terhadap perilaku konsumtif siswa kelas VII, VIII dan IX di SMP Negeri 41 Surabaya Tahun Pembelajaran 2014/2015..(3) Menganalisis pengaruh budaya kontemporer terhadap perilaku konsumtif siswa kelas VII, VIII dan IX di SMP Negeri 41 Surabaya Tahun Pembelajaran 2014/2015. dan (4) Menganalisis pengaruh konsep diri, teman sebaya dan budaya kontemporer secara bersama-sama terhadap perilaku konsumtif siswa kelas VII, VIII dan IX di SMP Negeri 41 Surabaya Tahun Pembelajaran $2014 / 2015$.

\section{METODE PENELITIAN}

Desain penelitian ini adalah kausal yang berguna untuk menganalisis hubungan antara variabel satu dengan yang lainnya atau bagaimana suatu variabel mempengaruhi variabel lainnya (Umar, 2003). Penelitian ini untuk membuktikan secara empiris pengaruh variabel bebas terhadap variabel terikat. Variabel dalam penelitian ini adalah sebagai berikut: Variabel bebas terdiri dari tiga variabel, yaitu: Konsep diri $\left(\mathrm{X}_{1}\right)$, Teman sebaya $\left(\mathrm{X}_{2}\right)$, Budaya kontemporer $\left(\mathrm{X}_{3}\right)$ dan Variabel terikat yaitu perilaku konsumtif $(\mathrm{Y})$.

Populasi penelitian adalah siswa di SMP Negeri 41 Surabaya. Berdasarkan data yang di dapat maka jumlah populasi dalam penelitian ini adalah seluruh siswa kelas VII, VIII dan IX yang terdiri dari 1070 orang siswa dan sampel dalam penelitian ini adalah sebesar 291 siswa sesuai dengan rumus Slovin (dalam Umar, 2003) sebagai berikut: 


$$
\mathrm{n}=\frac{\mathrm{N}}{\mathrm{N}\left(\mathrm{d}^{2}\right)+1}
$$

Keterangan: $\mathrm{n}=$ Ukuran sampel, $\mathrm{N}=$ Populasi, $\mathrm{d}=$ Taraf nyata atau batas kesalahan

Teknik pengumpulan data dalam penelitian ini digunakan dengan cara penyebaran angket. Teknik analisis data dalam penelitian dengan menggunakan regresi linier berganda.

\section{HASIL PENELITIAN DAN PEMBAHASAN}

Pengujian normalitas dimaksudkan untuk mengetahui apakah dalam model regresi, variabel pengganggu atau residual mempunyai distribusi normal. Model regresi yang baik adalah memiliki distribusi data normal atau mendekati normal untuk menguji apakah data normal atau tidak dapat dilakukan dengan analisis grafik, semakin sampel mendekati garis diagonal menunjukkan data terdistribusi normal. Hasil uji nornalitas seperti tampak pada gambar 1 .

\section{Normal P-P Plot of Regression Standardized Residual}

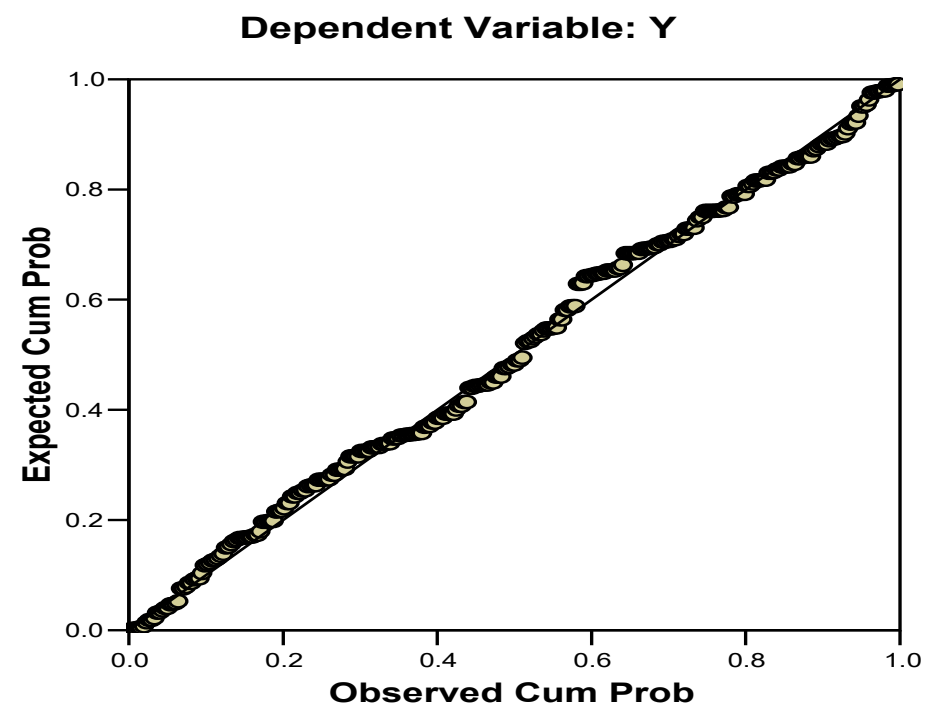

Gambar 1. Uji Normalitas

Pengujian terhadap multikolinieritas dilakukan guna mengetahui apakah variabel bebas tersebut tidak saling berkorelasi atau ada hubungan linier diantara variabel-variabel bebas dalam model regresi yang digunakan. Salah satu cara mendeteksi multikolinieritas adalah dengan mempergunakan uji korelasi Pearson. Diagnosis secara sederhana terhadap adanya multikolinieritas di dalam model regresi berganda adalah dengan cara melihat nilai Variance Inflation Factor atau VIF, bahwa satu data terjadi multikolinieritas apabila nilai VIF-nya lebih kecil dari 1 dan lebih besar dari 10. 
Tabel 1. Nilai-nilai Variance Inflation Factor

\begin{tabular}{|l|l|l|}
\hline No & Variabel & Nilai VIF \\
\hline 1 & Konsep diri $\left(\mathrm{X}_{1}\right)$ & 1,125 \\
\hline 2 & Teman sebaya $\left(\mathrm{X}_{2}\right)$ & 1,094 \\
\hline 3 & Budaya kontemporer $\left(\mathrm{X}_{3}\right)$ & 1,032 \\
\hline
\end{tabular}

Hasil pengujian menunjukkan bahwa tidak terjadi adanya gejala multikolinieritas karena nilai VIF lebih besar dari 1 dan lebih kecil dari 10.

Heteroskedastisitas adalah varian residual yang tidak sama pada semua pengamatan di dalam model regresi. Regresi yang baik seharusnya tidak terjadi heteroskedastisitas. Pengujian heteroskedastisitas dalam penelitian ini menggunakan teknik Scatterplot sebagai berikut. Model regresi yang baik adalah homoskedastisitas atau tidak terjadi heterokedastisitas. Salah satu cara untuk mendeteksi ada tidaknya heteroskedastisitas adalah dengan melihat grafik plot (ZPRED) dengan residualnya (SRESID). Apabila pada grafik scatterplot tidak ada pola yang jelas, serta titik-titik menyebar di atas dan di bawah angka 0 pada sumbu Y, maka dapat disimpulkan bahwa tidak terjadi heteroskedastisitas pada model regresi, seperti tampak pada gambar 1.

\section{Scatterplot}

\section{Dependent Variable: $Y$}

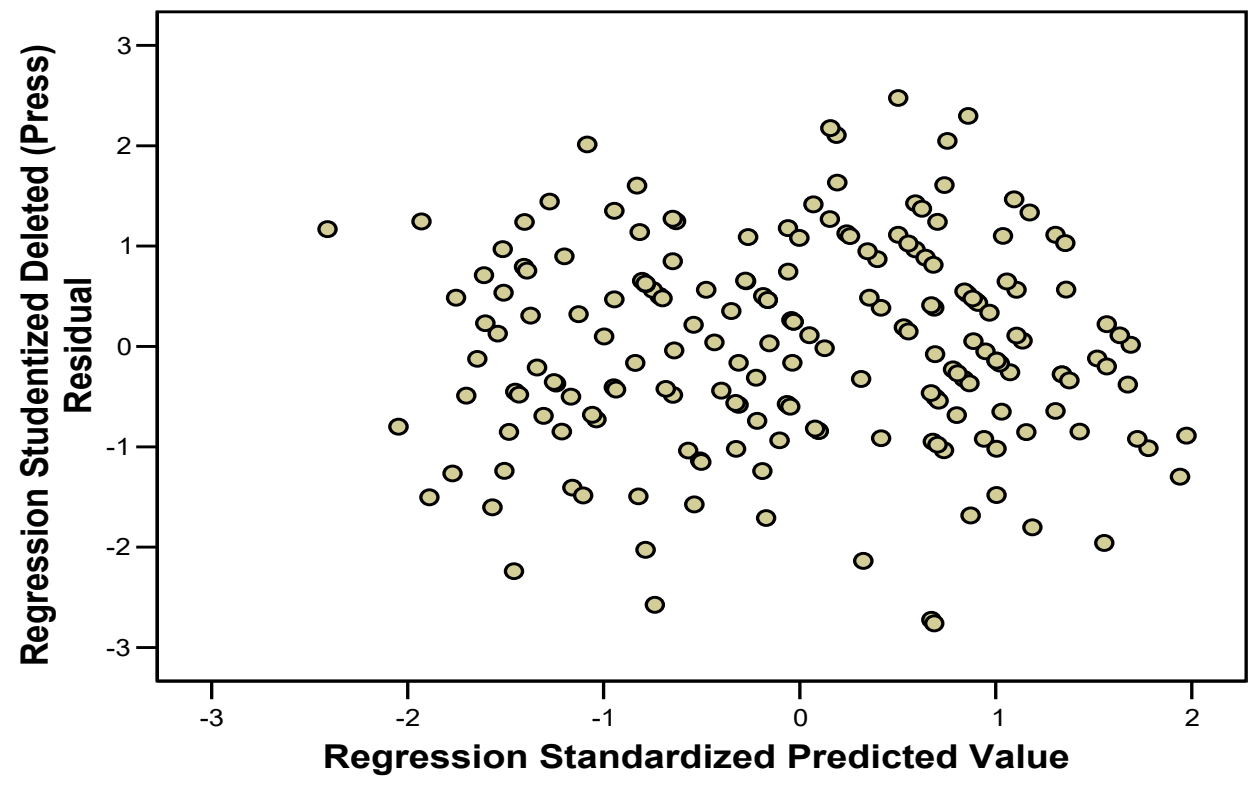

Gambar 2. Uji Heterokedastisitas

Uji linieritas bertujuan untuk mengetahui apakah sebaran data yang diuji mempunyai sebaran yang sesuai dengan garis linier. Teknik yang digunakan untuk menguji dengan menganalisis koefisien korelasi masing-masing variabel bebas dengan variabel terikat. 
Adapun hasil uji linieritas adalah sebagai berikut :

a. Hasil pengujian linieritas hubungan antara variabel konsep diri $\left(\mathrm{X}_{1}\right)$ terhadap perilaku konsumtif (Y) dapat diketahui bahwa nilai uji $\mathrm{F}$ Deviation from linearity adalah sebesar 1,171 dengan nilai signifikan lebih dari 5\% yaitu sebesar 0,310. Hal ini berarti hubungan antara konsep diri $\left(\mathrm{X}_{1}\right)$ dengan perilaku konsumtif $(\mathrm{Y})$ adalah linier.

b. Hasil pengujian linieritas hubungan antara variabel teman sebaya $\left(\mathrm{X}_{2}\right)$ terhadap perilaku konsumtif (Y) dapat diketahui bahwa nilai uji $\mathrm{F}$ Deviation from linearity adalah sebesar 3,211 dengan nilai signifikan kurang dari $5 \%$ yaitu sebesar 0,001 . Hal ini berarti hubungan antara teman sebaya $\left(\mathrm{X}_{2}\right)$ dengan perilaku konsumtif $(\mathrm{Y})$ adalah tidak linier

c. Hasil pengujian linieritas hubungan antara variabel konsep diri $\left(\mathrm{X}_{1}\right)$ terhadap perilaku konsumtif (Y) dapat diketahui bahwa nilai uji $\mathrm{F}$ Deviation from linearity adalah sebesar 0,985 dengan nilai signifikan lebih dari $5 \%$ yaitu sebesar 0,495 . Hal ini berarti hubungan antara konsep diri $\left(\mathrm{X}_{1}\right)$ dengan perilaku konsumtif $(\mathrm{Y})$ adalah linier.

Karena hubungan $\mathrm{X}_{2}$ dengan $\mathrm{Y}$ adalah tidak linier, sedangkan hubungan $\mathrm{X}_{1}$ dengan $\mathrm{Y}$ adalah linier, hubungan $\mathrm{X}_{3}$ dengan $\mathrm{Y}$ adalah linier, dengan demikian penelitian ini dapat disimpulkan bahwa uji linieritas sudah terpenuhi. Adapun hasil pengolahan data dengan metode regresi linier berganda adalah sebagai berikut :

Tabel 2. Persamaan Regresi Linier Berganda

\begin{tabular}{|l|l|}
\hline Variabel & Regression Coefficient \\
\hline Konstanta & 0,485 \\
\hline Konsep diri $\left(\mathrm{X}_{1}\right)$ & 0,287 \\
\hline Teman sebaya $\left(\mathrm{X}_{2}\right)$ & 0,431 \\
\hline Budaya kontemporer $\left(\mathrm{X}_{3}\right)$ & 0,180 \\
\hline
\end{tabular}

$Y=0,485+0,287 X_{1}+0,431 X_{2}+0,180 X_{3}$

Dari persamaan tersebut, dapat dijelaskan sebagai berikut:

a. Konstanta (a) yang dihasilkan sebesar 0,485 ini menunjukkan bahwa besarnya perilaku konsumtif adalah 0,485 dengan asumsi variabel konsep diri, teman sebaya dan budaya kontemporer tidak mempengaruhi.

b. Koefisien regresi (b) pada variabel konsep diri ( $\left.\mathrm{X}_{1}\right)$ adalah positif yaitu sebesar 0,287 artinya jika konsep diri naik satu satuan maka perilaku konsumtif akan naik sebesar 0,287 satuan dengan asumsi variabel teman sebaya $\left(\mathrm{X}_{2}\right)$ dan budaya kontemporer $\left(\mathrm{X}_{3}\right)$ adalah konstan.

c. Koefisien regresi (b) pada variabel teman sebaya $\left(\mathrm{X}_{2}\right)$ adalah positif yaitu sebesar 0,431 artinya jika teman sebaya naik satu satuan maka perilaku konsumtif akan naik sebesar 0,431 satuan dengan asumsi variabel konsep diri $\left(\mathrm{X}_{1}\right)$ dan budaya kontemporer $\left(\mathrm{X}_{3}\right)$ adalah konstan.

d. Koefisien regresi (b) pada variabel budaya kontemporer $\left(\mathrm{X}_{3}\right)$ adalah positif yaitu sebesar 0,180 artinya jika budaya kontemporer naik satu 
satuan maka perilaku konsumtif akan naik sebesar 0,180 satuan dengan asumsi variabel konsep diri $\left(\mathrm{X}_{1}\right)$ dan teman sebaya $\left(\mathrm{X}_{2}\right)$ adalah konstan.

Uji F digunakan untuk mengetahui pengaruh konsep diri, teman sebaya dan budaya kontemporer secara simultan terhadap perilaku konsumtif. Untuk menguji signifikansi hipotesis, maka hipotesis yang diuji adalah Hipotesis Nihil $\left(\mathrm{H}_{0}\right) . \mathrm{H}_{0}$ atas hipotesis ke-4 berbunyi "Diduga tidak ada pengaruh antara konsep diri, teman sebaya dan budaya kontemporer terhadap perilaku konsumtif'. Adapun hasil uji F adalah sebagai berikut:

Tabel 3. Hasil Uji F

\begin{tabular}{|l|l|l|l|l|}
\hline Model & Sum of Squares & Df & F & Sig. \\
\hline 1 Regression & 65,535 & 3 & 279,696 & $.000^{*}$ \\
Residual & 22,415 & 287 & & \\
Total & 87,950 & 290 & & \\
\hline
\end{tabular}

Nilai $F_{\text {hitung }}$ yang dihasilkan adalah 279,696 dengan nilai signifikansi sebesar 0,000 kurang dari 0,05 sehingga dapat disimpulkan bahwa konsep diri, teman sebaya dan budaya kontemporer secara simultan berpengaruh signifikan terhadap perilaku konsumtif. Berarti $\mathrm{H}_{0}$ ditolak dan hipotesis alternatif $\left(\mathrm{H}_{1}\right)$ yang ke-4 diterima karena terbukti bahwa ada pengaruh signifikan antara konsep diri, teman sebaya dan budaya kontemporer terhadap perilaku konsumtif siswa di SMPN 41 Surabaya.

Besarnya pengaruh konsep diri, teman sebaya dan budaya kontemporer secara simultan terhadap perilaku konsumtif dapat dilihat dari koefisien determinasi (R-square) yaitu :

Tabel 4. Koefisien Determinasi

Model Summary

\begin{tabular}{|l|r|r|l|lr|}
\hline Model & R & R Square & Adjusted R Square & \multicolumn{2}{|l|}{ Std. Error of the Estimate } \\
\hline 1 & $.863^{\mathrm{a}}$ & .745 & .742 & .27947 \\
\hline
\end{tabular}

a. Predictors: (Constant), budaya kontemporer(X3), teman sebaya (X2), konsep diri (X1)

b. Dependent Variable: perilaku konsumtif $(Y)$

Nilai R Square yang dihasilkan sebesar 0,745 menunjukkan bahwa perilaku konsumtif dipengaruhi oleh konsep diri, teman sebaya dan budaya kontemporer sebesar $74,5 \%$ sedangkan $25,5 \%$ dipengaruhi oleh faktor selain ketiga faktor.

Uji tdigunakan untuk mengetahui pengaruh konsep diri, teman sebaya dan budaya kontemporer secara parsial terhadap perilaku konsumtif.

Tabel 5. Hasil Uji t

\begin{tabular}{|l|r|r|r|r|}
\hline Variabel & \multicolumn{1}{c|}{$\mathrm{t}_{\text {hitung }}$} & \multicolumn{1}{l|}{ Sig. } & \multicolumn{1}{c|}{$\mathrm{r}$ parsial } & $\mathrm{r}^{2}$ parsial \\
\hline Konsep diri $\left(\mathrm{X}_{1}\right)$ & 10,150 & 0,000 & 0,514 & 0,264 \\
\hline Teman sebaya $\left(\mathrm{X}_{2}\right)$ & 21,684 & 0,000 & 0,788 & 0,621 \\
\hline Budaya kontemporer $\left(\mathrm{X}_{3}\right)$ & 6,779 & 0,000 & 0,372 & 0,138 \\
\hline
\end{tabular}


Berdasarkan tabel di atas adalah :

a. Nilai t-hitung pada variabel konsep diri $\left(\mathrm{X}_{1}\right)$ sebesar 10,150 dengan tingkat signifikan kurang dari 5\% yaitu 0,000. Hal ini berarti bahwa konsep diri $\left(\mathrm{X}_{1}\right)$ secara parsial berpengaruh signifikan terhadap perilaku konsumtif (Y). Besarnya pengaruh konsep diri (X1) terhadap perilaku konsumtif (Y) adalah 26,4\%. Hal ini diperkuat pendapatn Hartanto (2005) yang menyatakan bahwa perilaku dari individu akan dimotivasikan ke arah peningkatan konsep diri melalui merek yang telah memiliki arti simbolis tersebut.

b. Nilai t-hitung pada variabel teman sebaya $\left(\mathrm{X}_{2}\right)$ sebesar 21,684 dengan tingkat signifikan kurang dari 5\% yaitu 0,000. Hal ini berarti bahwa teman sebaya $\left(\mathrm{X}_{2}\right)$ secara parsial berpengaruh signifikan terhadap perilaku konsumtif (Y). Besarnya pengaruh teman sebaya (X2) terhadap perilaku konsumtif (Y) adalah 62,1\%. Hal ini diperkuat pendapat Tambunan (2006) bahwa perilaku konsumtif dipengaruhi oleh dua faktor yaitu faktor internal dan faktor eksternal. Dalam penelitian ini faktor perilaku konsumtif yang lebih ditekankan adalah pengaruh kelompok teman sebaya yang termasuk dalam faktor eksternal dari kelompok sosial.

c. Nilai t-hitung pada variabel budaya kontemporer $\left(\mathrm{X}_{3}\right)$ sebesar 6,799 dengan tingkat signifikan kurang dari 5\% yaitu 0,000 . Hal ini berarti bahwa budaya kontemporer $\left(\mathrm{X}_{3}\right)$ secara parsial berpengaruh signifikan terhadap perilaku konsumtif (Y). Besarnya pengaruh budaya kontemporer (X3) terhadap perilaku konsumtif (Y) adalah 13,8\%. Hal ini diperkuat pendapat Wang dan $\mathrm{Xu}$ (2009) yang menyatakan bahwa budaya yang dipengaruhi oleh era globalisasi akan berubah menjadi budaya kontemporer yaitu budaya yang terbentuk adanya gaya hidup yang dipengaruhi oleh era globalisasi (Wang dan Xu, 2009)

\section{Pengaruh konsep diri terhadap perilaku konsumtif}

Berkaitan dengan hasil penelitian ini pada hipotesis pertama menyatakan bahwa konsep diri berpengaruh signifikan terhadap perilaku konsumtif. Hipotesis pertama terbukti bahwa konsep diri mempengaruhi perilaku konsumtif (Y). Hal ini dapat dilihat pada nilai signifikan variabel konsep diri sebesar $0,000(<0,05)$. Hal ini disebabkan bahwa kepuasan diri yang rendah akan menimbulkan harga diri (self esteem) yang rendah pula dan akan mengembangkan ketidakpercayaan yang mendasar pada dirinya. Sebaliknya, bagi individu yang memiliki kepuasan diri yang tinggi, kesadaran dirinya lebih realistis, sehingga lebih memungkinkan individu yang bersangkutan untuk merupakan keadaan dirinya dan memfokuskan energi serta perhatiannya ke luar diri, dan pada akhirnya dapat berfungsi lebih konstruktif.

Selain itu konsep diri merupakan konsep yang menjanjikan untuk riset konsumen, dan kegagalan pengendalian diri mungkin merupakan penyebab penting dari pembelian impulsif (Baumeister, 2013). Pendapat ini didukung dengan penelitian yang dilakukan Pimthong (2015) menyimpulkan bahwa efek langsung masa depan orientasi \& pengendalian diri sikap mereka terhadap perilaku konsumsi cukup berbeda, menunjukkan bahwa efek siswa dari Malaysia lebih tinggi dibandingkan dengan siswa dari Thailand. Perilaku 
konsumtif mereka dipengaruhi oleh materialisme, kekuatan karakter, asuhan keluarga, pengaruh sesama, dan pengaruh media sehingga menyebabkan mahasiswa Malaysia menskor lebih tinggi perilaku konsumtifnya dibandingkan dari Thailand.

Penelitian ini juga mendukung penelitian yang dilakukan oleh Gountas dan Mavondo (2003) menyimpulkan bahwa meramalkan perilaku konsumen menjadi sebuah isu sangat penting bagi pemasar. Sebab secara individu disebabkan adanya sikap, motif, sifat-sifat kepribadian dan gaya belajar serta konsep diri. Melalui faktor-faktor tersebut akan membentuk perilaku konsumen aktual dengan berbagai tingkatan kesuksesan.

\section{Pengaruh teman sebaya terhadap perilaku konsumtif}

Pada hipotesis kedua menyatakan bahwa teman sebaya berpengaruh signifikan terhadap perilaku konsumtif. Hipotesis kedua terbukti bahwa teman sebaya mempengaruhi perilaku konsumtif (Y). Hal ini disebabkan nilai sig, teman sebaya menunjukkan nilai $0,000 \quad(0,000<0,05)$. Dapat disimpulkan bahwa $\mathrm{H}_{\mathrm{o}}$ ditolak dan $\mathrm{H}_{1}$ diterima sehingga dapat diartikan bahwa teman sebaya mempengaruhi perilaku konsumtif (Y). Hal ini disebabkan lingkungan teman sebaya itu mempunyai fungsi penting sebagai pengganti keluarga, mengajarkan berhubungan dan menyesuaikan diri dengan orang lain dan memperluas cakrawala anak, sehingga ia menjadi orang yang lebih baik. Makin bertambah usia seseorang peranan lingkungan pendidikan lainnya (yakni sekolah dan masyarakat) semakin penting meskipun pengaruh lingkungan keluarga masih tetap berlanjut. Hal ini disebabkan kelompok sebaya anak mempelajari kebudayaan masyarakat. Bahwa melalui kelompok sebaya itu anak belajar bagaimana menjadi manusia yang baik sesuai dengan gambaran dan cita-cita masyarakatnya, tentang kejujuran, keadilan, kerja sama, dan tanggung jawab. Sehingga kelompok sebaya menjadi wadah dalam mengajarkan mobilitas sosial. Melalui pergaulan di dalam lingkungan kelompok sebaya itu anak-anak yang berasal dari kelas sosial bawah menangkap nilai-nilai, ide-ide, cita-cita, dan pola tingkah laku anak dari golongan menengah ke atas demikian juga sebaliknya.

Hasil penelitian ini didukung penelitian yang dilakukan oleh Kiriinya dkk (2014) menyatakan bahwa anak secara signifikan mempengaruhi keputusan pembelian keluarga di Kenya, disebabkan adanya tekanan teman sebaya. Penelitian lain yang mendukung hasil penelitian ini adalah penelitian yang dilakukan oleh Makgosa dan Mohube (2007) yang menyatakan bahwa adanya pengaruh teman sebaya terhadap keputusan pembelian produk orang muda hingga dewasa. Selain itu disebabkan teman sebaya sebagai dua atau lebih banyak orang yang berinteraksi untuk mencapai baik tujuan-tujuan individual atau timbal balik. (Kiriinya, dkk 2014).

\section{Pengaruh budaya kontemporer terhadap perilaku konsumtif}

Pada hipotesis ketiga yang berbunyi budaya kontemporer berpengaruh signifikan terhadap perilaku konsumtif. Hal ini disebabkan nilai sig, budaya kontemporer menunjukkan nilai $0,000(0,000<0,05)$. Dapat disimpulkan bahwa $\mathrm{H}_{\mathrm{o}}$ ditolak dan $\mathrm{H}_{1}$ diterima sehingga dapat diartikan bahwa budaya kontemporer $\left(\mathrm{X}_{2}\right)$ mempengaruhi perilaku konsumtif $(\mathrm{Y})$. Selain itu disebabkan 
bahwa perilaku konsumtif dari seorang remaja juga tergantung seberapa besar pengaruh gaya hidup yang ada di lingkungan sekitarnya dan kelas sosial yang dimiliki tiap individu. Keadaan ekonomi tiap individu yang berbeda dapat mempengaruhi diri mereka untuk mengkonsumsi barang yang berlebihan sebagai bentuk bahwa remaja dapat mengikuti perkembangan yang terjadi saat ini. Proses tersebut berawal dari modal dari seseorang, yaitu diantaranya 1. kondisi objektif seorang remaja terhadap suatu hal, 2. habitus yaitu kebiasaan seseorang dalam kehidupan sehari-harinya, 3. disposisi, 4. gaya hidup, 5. sistem tanda, dan 6. selera seseorang terhadap hal baru. Dari proses inilah kenudian timbul adanya dimensi gaya hidup yang berhubungan dengan aktivitas (bagaimana seseorang dapat melakukan aktivitas dalam menghabiskan waktu luangnya), minat (apa yang menarik atau yang paling penting dari diri seseorang), dan opini (pendapat dan pandangan mereka terhadap dunia mereka dan dunia sekitarnya)

Penelitin ini didukung dengan penelitian yang dilakukan oleh Wang \& Xu (2009) menyimpulkan bahwa kultural dan budaya kontemporer mahasiswamahasiswa Cina pada dasarnya stabil dan lama bertahan mengenai budaya orang Cina kuno. Pendapat senada juga disampaikan hasil penelitian yang dilakukan JungdanKau (2004) yang menggatakan bahwa faktor utama yang memengaruhi perilaku konsumtif adalah kebudayaan. karena budaya merupakan kebiasaan yang sering dilakukan dan sering ditemui sehingga mampu memberikan pengaruh terhadap perilaku konsumtif.

\section{Pengaruh konsep diri, teman sebaya dan budaya kontemporer terhadap perilaku konsumtif}

Pada hipotesis keempat yang berbunyi konsep diri, teman sebaya dan budaya kontemporer secara bersama-sama berpengaruh signifikan terhadap perilaku konsumtif. Hal ini disebabkan nilai signifikan dari ketiga variabel bebas (konsep diri, teman sebaya dan budaya kontemporer) sebesar 0,000 $(<0,05)$, artinya kurang dari 0,05 . Sehingga $H_{o}$ ditolak dan $H_{I}$ diterima yang artinya variabel bebas (konsep diri, teman sebaya dan budaya kontemporer) secara bersama-sama berpengaruh terhadap perilaku konsumtif. Hal ini disebabkan bahwa perilaku konsumsi dengan tujuan untuk memperoleh kepuasan setinggi-tingginya dan mencapai tingkat kemakmuran dalam arti terpenuhinya berbagai macam kebutuhan. Keputusan pembelian untuk konsumsi cukup beragam, sehingga mengakibatkan jenis-jenis konsumsi juga mempunyai banyak ragam. Banyak faktor yang mempengaruhi perilaku konsumsi seseorang baik yang berasal dari dalam dirinya mupun dari luar dirinya atau lingkungannya. Faktor tersebut bersifat obyektif maupun subyektif.

Penelitian ini didukung dengan penelitian yang dilakukan oleh Durmaz (2014) menyimpulkan bahwa perilaku konsumen dipengaruhi tidak hanya oleh kepribadian-kepribadian konsumen dan motivasi, tetapi juga dipengaruhi oleh hubungan di dalam keluarga seperti teman sebaya. Penelitian lain yang sependapat dengan penelitian ini adalah yang dilakukan oleh Durmaz Yakup, Celik Mücahit dan Oruc Reyhan (2011)menyimpulkan bahwa (1) Usia dan masa hidup, pendidikan, gaya hidup dan kepribadian secara bersama-sama berpengaruh terhadap perilaku konsumen di Polandia.(2) Usia dan masa hidup, 
berpengaruh terhadap perilaku konsumen di Polandia. (3) Pendidikan berpengaruh terhadap perilaku konsumen di Polandia. (4) Gaya hidup berpengaruh terhadap perilaku konsumen di Polandia dan (5) Kepribadian berpengaruh terhadap perilaku konsumen di Polandia. Penelitian lain yang mendukung adalah penelitian yang dilakukan oleh Primadini dan Budiani (2009) menyimpulkan bahwa (1) Gaya Hidup Dan Kelas Sosial secara bersama-sama berpengaruh terahdap Perilaku Konsumtif Pada Remaja Di SMA Trimurti Surabaya (2) Gaya Hidup berpengaruh terhadap Perilaku Konsumtif Pada Remaja Di SMA Trimurti Surabaya. dan (3) Kelas Sosial berpengaruh terahdap Perilaku Konsumtif Pada Remaja Di SMA Trimurti Surabaya.

\section{SIMPULAN}

Berdasarkan hasil analisis dan pembahasan, diperoleh simpulan bahwa konsep diri berpengaruh signifikan terhadap perilaku konsumen, mengisyaratkan bahwa konsep diri merupakan salah satu faktor yang mempengaruhi perilaku konsumtif siswa dalam proses pembelian. Semakin memiliki konsep diri yang kuat ada kecenderungan perilaku konsumtinya juga meningkat. Hal ini disebabkan adanya dampak yang paling serius dari terjadinya konflik sehingga dapat melemahkan konsep diri seseorang. Jika seseorang secara terus menerus tidak mampu mengatasi konflik yang menimpanya, persepsinya tentang kemampuan dirinya mengontrol lingkungan menjadi negatif. Jika konflik ini makin tidak dapat ditangani, ia akan mulai menyerang konsep diri orang lain sehingga konsep diri melemah dan akhirnya terpengaruh terhadap perilaku konsumtif.

Teman sebaya berpengaruh signifikan terhadap perilaku konsumtif, disebabkan persahabatan pada siswa sekolah pada umumnya terjadi atas dasar ketertarikan dan aktivitas bersama yang bersifat timbal balik dan memiliki sifat-sifat antara lain adanya saling pengertian, saling membantu, saling percaya, saling menghargai dan menerima. Sehinga apabila teman sebaya tersebut selalu mengajak ke mall untuk membeli sesuatu seringkali tidak rasional dalam membeli.

Budaya kontemporer berpengaruh signifikan terhadap perilaku konsumtif, disebabkan adanya perkembangan iptek yang cepat berdampak pada budaya yang cenderung berubah sehingga secara langsung maupun tidak langsung mempengaruhi aktifitas siswa yaitu siswa membeli produk tertentu karena adanya promosi yang gencar dilakukan perusahaan dan tanpa adanya sikap yang rasional siswa tertarik membeli sesuatu.

Konsep diri, teman sebaya dan budaya kontemporer secara bersama-sama berpengaruh signifikan terhadap perilaku konsumtif. Disebabkan karena konsep diri yang lemah akan mudah terpengaruh oleh adanya iklan yang memang bertujuan menarik pembeli untuk membelinya. Apalagi dukung dengan teman sebaya yang memiliki sifat-sifat saling pengertian, saling membantu, saling percaya, saling menghargai dan menerima, sehingga akan lebih mudah tertarik membelinya tanpa memperhatikan penting tidaknya barangyang terbeli. Selain itu apabila diduknng media yang berkembang cepat akan mudah mengarah tertarik untuk membeli sesuai hanya untuk mengikuti 
tren yang memang harus perlu diikuti. Sebab apabila tidak mengikuti trend akan dianggap kuno.

\section{DAFTAR RUJUKAN}

Baron, R. A dan Donn Byrne. 2003. Psikologi Sosial . Jakarta: Erlangga

Dariyo, Agoes. 2007. Psikologi Perkembangan: Anak Tiga Tahun Pertama. Bandung: Refika Aditama

Durmaz , Y., .2014. The Influence of Cultural Factors on Consumer Buying Behaviour and an Application in Turkey. Global Journal of Management and Business Research: E Marketing.Volume 14 Issue 1 Version 1.0.

Gountas, John, dan Mavondo, Felix. 2003. Self-concept and Motivation as predictors of actual consumer behaviour ANZMAC Conference Proceedings Adelaide 1-3 December

Gumulya, J dan Widiastuti, M. 2013. Pengaruh Konsep Diri Terhadap Perilaku Konsumtif Mahasiswa Universitas Esa Unggul. Jurnal Psikologi Volume 11 Nomor 1, Juni. Fakultas Psikologi Universitas Esa unggul.

Jung, Kwon dan Kau, Keng .2004.Culture's Influence on Consumer Behaviors: Differences Among Ethnic Groups in a Multiracial Asian Country. Advances in Consumer Research Volume 31.

Kiriinya, S.N., Bwisa, H., dan Orwa, G.O., 2014. Children's Peer Group Influence on Family Purchase Decisions in Kenya, International Journal of Advanced Research in Management and Social Sciences, Vol. 3 No. 11, November.

Makgosa, R., and Mohube, K., 2007. Peer influence on young adults' products purchase decisions. African Journal of Business Management pp. 064071, June.

Mangkunegara, A.P., 2004. Manajemen Sumber Daya Manusia Perusahaan cetakan pertama, penerbit PT. Remaja Rsodakarya. Bandung

Nayeem, T., 2012. Cultural Influences on Cunsumer Behavior. International Journal of Business and Management. Vo. 7, No. 21. ISSN 1833-3850. E-ISSN 1833-8119. Published by Canadian of Science and Education.

Pimthong, Saran, 2015 Psychosocial Factors Correlated with Sufficient Consumption Behavior of Students in Thailand and Malaysia. Behavioral Science Research Institute, Srinakharinwirot University, Bangkok, Thailand .Asian Social Science; Vol. 11, No. 4;

Primadini I, Y. dan Budiani, M.S. 2009. Hubungan Antara Gaya Hidup Dan Kelas Sosial Dengan Perilaku Konsumtif Pada Remaja Di SMA Trimurti Surabaya. Program Studi Psikologi, FIP, Unesa. Volume 03 Nomor 02 Tahun 2014. 
Primadini, Y, dan Budiani, M.S., 2014.Hubungan Antara Gaya Hidup Dan Kelas Sosial Dengan Perilaku Konsumtif Pada Remaja Di SMA Trimurti Surabaya, Character. Volume 03 Nomor 02 Tahun 2014

Saad, Mohamad dan Metawie, M.,2015. Store Environment, Personality Factors and Impulse Buying Behavior in Egypt: The Mediating roles of Shop Enjoyment and Impulse Buying Tendencies, Journal of Business and Management Sciences ,Vol. 3, No. 2, 2015, pp 69-77.

Santrock. 2007. Life-Span Development. Seven Edition. New York: Mc GrawHill Companies, Inc.

Soekamto, S., 2007. Sosiologi Suatu Pengantar, (Jakarta: PT. Rajagrafindo Persada

Sumartono. 2002. Terperangkap dalam Iklan: Meneropong Imbas Peran Iklan Televisi. Bandung: Penerbit Alfabeta.

Sumarwan, U. 2011. Perilaku Konsumen: Teori dan Penerapannya dalam Pemasaran. Bogor: Ghalia Indonesia.

Tirtarahardja, Umar \& La Sulo. 2005. Pengantar Pendidikan. PT Rineka Cipta. Jakarta.

Umar, H. 2003. Riset Pemasaran dan Perilaku Konsumen. Jakarta: Erlangga.

Wang, F. and $\mathrm{Xu}, \mathrm{S} ., 2009$, Impact of Cultural Values on Consumption Behavior: A Survey of Contemporary Chinese University Students. Guangdong University of Foreign Studies, Intercultural Communication Studies XVIII:1.

Yakup, D., Mücahit, C dan Reyhan, O,. 2011. The Impact of Cultural Factors on the Consumer Buying Behaviors Examined through An Impirical Study. International Journal of Business and Social Science Vol. 2 No. 5 